\title{
Attitudes toward female circumcision among Somali immigrants in Oslo: a qualitative study
}

This article was published in the following Dove Press journal:

International Journal of Women's Health

18 January 2012

Number of times this article has been viewed

\author{
Abdi A Gele 1,2 \\ Bernadette Kumar ${ }^{3}$ \\ Karin Harsløf Hjelde ${ }^{3}$ \\ Johanne Sundby ${ }^{2}$ \\ 'The Department of Social Science, \\ Oslo University College, ${ }^{2}$ Section \\ for International Health, Department \\ of General Practice and Community \\ Medicine, University of Oslo, \\ ${ }^{3}$ Norwegian Center for Minority \\ Health Research, Oslo, Norway
}

\begin{abstract}
Due to its negative impact on public health, female circumcision (FC) has gained increased attention from international communities and the Norwegian public in recent decades. In 1995, the Norwegian government outlawed the practice and simultaneously developed a package of measures aimed at preventing and ultimately eradicating FC in Norway. Like many other Western countries, immigrants of Somali descent constitute the largest immigrant group in Norway from countries with FC traditions. Although this immigrant group is often perceived as a cultural society that supports FC generally as a practice, there appears to be a lack of studies that explore the impact of acculturation and the Western social context on Somali immigrants' attitudes toward the practice. Against this background, this paper explores the attitudes of Somalis living in Oslo, Norway to the practice of FC. Findings from this qualitative study indicate that Somalis in Oslo have, to a large extent, changed their attitude toward the practice. This was proven by the presence in Oslo of a large number of Somali parents who left their daughters uncut as well as Somali girls, boys, men, and women who attribute being uncircumcised a high status. This study adds to the knowledge of the process of abandonment of FC among immigrants in the Western countries. The study highlights the success that has been achieved in improving attitudes toward the practice of the Somali community in Oslo, Norway, as well as emerging challenges that need to be addressed further.
\end{abstract}

Keywords: female circumcision, attitude, behavior, immigrants, Somalis

\section{Background}

Globally, over 140 million girls and women have undergone female circumcision (FC), with nearly 3 million girls at risk for the practice every year. ${ }^{1}$ The majority of these girls and women live in 28 African countries. There are also pockets in Asia and Western countries that host immigrants from countries with FC traditions. Somalia, which is a country characterized by decades of civil war that propelled approximately $25 \%$ of its people to migrate to Western countries such as Norway, has the highest prevalence of FC in the world (99\%). ${ }^{2}$ The presence of about 30,000 Somali immigrants in Norway was the catalyst that fueled interest in exploring attitudes toward FC among Somali immigrants in Oslo.

Female genital mutilation (FGM), or FC, which is the term we use in this paper and is a literal translation from the Somali language (gudniinka dumarka), is a traditional social practice involving the removal or injury of the external female genitalia for nontherapeutic reasons. The practice is often performed on girls between the ages of 0-9 years, thus making it one of the most horrific child tortures of our time. It is a painful surgical procedure usually carried out without anesthesia, which often results
Correspondence: Abdi A Gele Department of Social Science, Oslo University College, Pilestredet 35 0167 Oslo, Norway

Tel +479682 2030

Fax +47 22453600

Email abdi-ali.gele@hioa.no 
in serious psychological and medical complications for the girls and women. ${ }^{3}$ The victims of FC suffer permanent and irreversible health damage that may negatively affect their health over the course of their entire life. ${ }^{4}$ The immediate problems that children may experience during the procedure are extreme pain, excessive bleeding, shock, and infections. ${ }^{5}$ Other obvious complications include urine retention, difficulties in menstruation, and impaired sexual pleasure. ${ }^{6}$ Invasive forms of FC can also cause complications in childbirth, resulting in the need for cesarean sections or episiotomy, such as perineal tears or postpartum hemorrhage as well as an increased risk of stillbirth and neonatal death. ${ }^{7,8}$ Additionally, increased risk of cervical cancer ${ }^{9}$ and death have also been associated with the practice. ${ }^{10}$

In addition to the negative health consequences of FC, it is imperative to highlight that the practice reflects gender inequality, establishing an extreme form of female discrimination. Progress toward the abandonment of girls' circumcision may therefore contribute to the empowerment of women (Millennium Development Goal [MDG] 3), improvement of maternal health (MDG 5), and a reduction in child mortality (MDG 4). Accordingly, for the good health and human rights of women and children, the United Nations has denounced all forms of the practice, rejecting any shift toward milder forms as well as to the medicalization of the practice. ${ }^{11}$

Despite universal condemnation, millions of girls and women live today with the gross physical and psychological damage caused by this practice. ${ }^{12}$ Although the majority of the girls who are at risk for the practice live in Africa, FC is no longer only confined to countries where it has been traditionally performed, but also occurs in Western countries hosting immigrants, where it also constitutes a significant public health concern. ${ }^{13}$ Persistent war, civil unrest, and droughts in FC practicing-countries in Africa, for example, Somalia, Ethiopia, and Eritrea, have resulted in an influx of refugees to Western Europe and North America. Consequently, immigrants from Somalia became the largest FC-practicing communities in Scandinavia, Britain, and North America. ${ }^{14-19}$

Somalis are Somali-speaking people who inhabit the Horn of Africa including Somalia, the northeastern region of Kenya, the Ogaden region of Ethiopia, and the Republic of Djibouti. They are the most homogeneous group of people in Africa, and 98\% of Somalis speak the Somali language. ${ }^{19}$ Although FC has been universally practiced by the Somali people, ${ }^{2}$ there is no definitive evidence to date of exactly when and why FC began among Somalis. However, efforts toward the abandonment of FC took root in Somalia as early as the 1970s. The latest functional Somali government collapsed in 1991 and the country descended into a civil war that continues to this day. Since then, the FC programs in Somalia have relied on efforts by international and local organizations. Nevertheless, there have been questions about the level of coverage of these programs, the overall effectiveness of projects, what lessons have been learned, and the best practices that have emerged. ${ }^{2}$ Despite the existence of these programs, the evidence shows that the prevalence of FC is universal in Somalia, with $85 \%$ of urban and $98 \%$ of rural women undergoing the severest form (Type 3). ${ }^{20-22}$ The female participants in these studies overwhelmingly intend to circumcise their daughters, with $76 \%$ and $50 \%$ of rural and urban women, respectively, planning to perform it in its severest form.

\section{Culture and ritual beliefs that perpetuate FC}

Although FC predates all contemporary global religions that practice it today, ${ }^{23}$ the majority of Somalis believe that FC is mandated by Islam. ${ }^{24}$ Even so, the Koran does not prescribe FC, nor is it carried out in Saudi Arabia, which is the epicenter of Islam. ${ }^{25}$ Similarly, the vast majority of Muslims around the world do not circumcise girls, while some Muslim imams have addressed girls' circumcision as a "satanic practice." 26 Despite this, milder forms of FC in Somalia are called "sunna," which literally means "tradition" in Arabic. For Somalis though, "sunna" means any tradition of the Prophet Mohamed that his followers should preserve. As a result, many Somalis are hesitant to abandon any practice which uses the name "sunna." 27 The awareness campaigners in Somalia rarely encourage the abandonment of all forms of FC, but often denounce Pharaonic circumcision (Type 3), which simply carries an anti-Islamic name that people can easily question, while the Sunni form remains largely untouched by campaigners because of the Islamic name it carries. ${ }^{2}$ The religious aspect of FC in Somalia is very complex due to the fact that cultural beliefs and religion in this community intermingle, and locals take a number of cultural issues as religious doctrine.

"Culture" can be seen as a collection of learned beliefs, traditions, and codes of behavior commonly shared among members of a particular community, ${ }^{28}$ with every member in that community being expected to be bound by that culture. Many communities consider FC as their traditional custom and as a part of their culture that defines their identity and brings them together. In Somali culture, there is no clear-cut 
partitioning between male and female circumcisions. Both forms are called "gudniin," meaning "circumcision." It is argued that, regardless of gender, every child in the family must be circumcised, as circumcision of both girls and boys is equally perceived as a normal aspect of being a Somali, ${ }^{27}$ and the age range of circumcision is similar among both Somali boys and girls ( $<10$ years). It is the mother's duty to make arrangements for the circumcision of her daughters, whereas the father is expected to organize the circumcision of his sons. There is an inclination that an uncircumcised person's prayers are not accepted by God, while "buuryo qab" (uncircumcised) is the worst kind of insult one can hurl at another. Male circumcision is a religious mandate to Muslims, although FC is un-Islamic. ${ }^{25}$ However, being uncircumcised remains outside of the accepted Somali cultural milieu, and is incompatible with a Somali's perspective of what it means to be a person who is "clean" and qualified for marriage.

Nonetheless, culture is not static but, rather, a dynamic process that changes with the circumstances that surround it. Factors such as migration, social context, and the level of education can amend a culture and play a significant role in reshaping a community's norms, behaviors, and values. ${ }^{27}$ Once migration occurs, attitudes toward continuing FC may change. When FC-practicing immigrants arrive in a new country such as Norway, they experience different perceptions of parental practices, women's status, women's role in society, and the sociocultural and economic values that define it, which may lead to a reappraisal of initial perceptions concerning FC. ${ }^{29}$ In this paper, we explore the attitudes to FC among a group of immigrants from Somalia where FC is the norm who have resettled in Norway where FC is not only illegal but also antagonistic to the value system of the country.

\section{FC among Somalis in Norway}

There are currently about 30,000 Somalis living in Norway as their new home country, thus constituting the largest group of African immigrants and the third largest nonWestern group of immigrants in Norway. FC is almost universal among first-generation Somalis in Norway, with an estimated $80 \%$ of Somali women in Norway having experienced infibulations. ${ }^{3,30} \mathrm{FC}$ was criminalized in Norway in 1995 and the law against FC states that "any person who willfully performs a procedure on a woman's genital organs that injures or permanently changes the genital organs will be penalized for female genital mutilation. The penalty is a term of imprisonment of up to 3 years, or up to 6 years." ${ }^{11}$ The Norwegian action plan against FC was established in 2000, with the rationale of the action plan being to prevent $\mathrm{FC}$ and to accomplish a behavioral change toward the practice. ${ }^{31}$

There were 3800 girls from FC-practicing countries in Norway in 2007 who were at the age of circumcision. Despite the large number of suspected cases of circumcision that were reported between 2006 and 2007, only 15 girls were officially confirmed to be circumcised. However, when and where the procedure had taken place was not known. ${ }^{32}$ An unverified report by Norwegian national television showed that girls were being sent to Somalia/Somaliland for circumcision to avoid the legal restrictions in Norway. A similar situation was reported from Somali communities in Britain. ${ }^{33}$ Even so, there has been no single study investigating the incidence of girls' circumcision carried out in Western countries that host immigrants. ${ }^{12}$ Some researchers have postulated that the lack of concrete evidence about the incidence of the practice among Somalis in Western countries may reflect their abandonment of the practice. ${ }^{34}$ It is highly likely that where FC is not a social norm and is not associated with social status by the majority culture, some of the social forces influencing its continuation may be eroded. ${ }^{19}$ A prior study reveals that the longer that Somalis stay in exile, the higher the likelihood that they will abandon FC. ${ }^{15}$ An anthropological study in Norway stated that FC, which is perceived as cleansing and a sign of womanhood in Somalia, has now been reinterpreted by Somali women in exile as "amputation and even mutilation." ${ }^{\prime 16}$

Social conditions are dynamic processes that change over time and so it is with the practice of FC; hence, systematic surveillance is necessary in monitoring the development and progress of behavioral changes toward FC. Nevertheless, attitude change toward FC among Somali immigrants in Scandinavia, including Norway, has so far received little attention in the literature and thus a limited amount of knowledge is available to guide policymakers and campaigners in designing appropriate measures that are aligned with dynamic processes of attitude change toward FC among Somali immigrants. Therefore, as part of a broad-based study on FC among Somalis in Norway and in Somalia, this article explores Somali immigrants' attitude toward FC, using focus group discussions (FGDs) and personal interviews with 38 male and female participants living in Oslo, Norway.

\section{Methods \\ Participants and data collection}

A qualitative study using four FGDs and personal interviews was carried out in Oslo between April and July of 2011. 
An FGD is considered important in providing a dynamic environment in which participants motivate each other's view and has proven effective when exploring sensitive topics such as FC. ${ }^{35}$ Moreover, FGDs were found to be important in research focusing on minority groups. ${ }^{36}$

A purposive sampling of 22 Somalis aged $>18$ years was included in the FGDs, with the persons recruited for the study demonstrating diversity in terms of their education, age, and number of years having lived in Norway. Each FGD involved five to six persons who were divided by gender and age. Two focus groups were comprised of women and two of men, with two groups consisting of people $\leq 25$ years of age and two $>25$. The smaller-sized FGDs permitted the facilitator to easily explore the participants' responses in depth.

Prior to data collection, the participants were informed about both the objectives of the study and the expected duration of the interviews. Verbal consent was obtained from participants with the assurance that they could withdraw from the study at any time without any negative consequences. The study was approved by the Norwegian Ethics Committee.

The first author, a Somali born male who is bilingual in Somali and English, conducted the interviews and FGDs. Being a male researcher did not negatively affect the interviews but instead helped improve the openness of the study's participants. The researcher, a member himself of the Somali community in Oslo, has previously conducted a number of fieldwork data collections among Somalis in Oslo and has long enjoyed trust and respect among his community. Despite the sensitivity of the research topic, as FC is illegal in Norway, the participants never associated the researcher with authority, a superior power, or the mainstream community. Hence, the participants discussed the topic openly without fear of negative consequences or stigma.

FGDs took place in various local community centers according to the groups' choice. Prior to the discussion, refreshments were offered to not only stimulate discussion among the members to get to know each other better but also to uphold the cultural expectations of hospitality. All the FGDs were audiotaped and each FGD lasted 1-2 hours. In addition, separate audiotaped interviews lasting 30 minutes each were conducted among 16 persons. The participants in the interviews were people who were not included in the FGDs. All of the study participants were native Somali speakers. During the interviews, we used an interview guide and extensively probed the participants' responses. In the FGDs, interactions between individuals were provoked and we continued the interview process until it was clear that no new information was emerging from the additional interviews - that is, until saturation was achieved.

\section{Content of the interviews}

The term "female genital mutilation" was not well received by participants. As a result, we adopted "female circumcision," which is a term that is used locally. During the interviews, participants were asked about their understanding of FC, their pre- as well as postmigration experiences of FC, and their perspectives regarding the continuation or discontinuation of all forms of FC. The reasons behind the motivation for the continuation or discontinuation of the practice in a Somali context, as well as the factors considered detrimental for the continuation or discontinuation of the practice, were all explored.

\section{Analysis}

The first author translated the audiotaped interviews into English. To validate their content, the translated interviews were verified with the respondents and transcribed verbatim. The transcripts were systematically read and reread to identify themes of importance to the description of the phenomenon. ${ }^{37}$ We then applied a thematic analysis to identify, analyze, and report on the identified themes. ${ }^{38}$ The coding process involved recognizing an important theme and encoding it prior to interpretation. ${ }^{39}$ According to Leininger, ${ }^{40}$ themes can be identified by bringing together fragments of ideas, experiences, and beliefs that are often meaningless when viewed alone. For that reason, themes that emerged from the informants' stories were pieced together to form a comprehensive picture of the participants' shared experience. ${ }^{41}$ The themes that were identified through coding were divided into categories based on the participants' experience, knowledge, and attitude toward FC..$^{42}$ The consistency of the findings from different methods we used (ie, the FGDs, interviews, and quantitative data that will be published elsewhere), has served to ensure the trustworthiness and credibility of the study's results.

\section{Results}

Out of 38 participants in this study, 17 (45\%) were male and $21(55 \%)$ were female. Their ages ranged from 19 to 56 years, with a mean age of 33 years. The participants' years of residence in Norway ranged from 2 to 22 years, with a mean length of residence of 10 years. Educationally, the majority of the study participants had a secondary school-level education, though a few had a college or university education. The participants' responses to most of the questions were 
akin in both FGDs and personal interviews; as a result, the responses could be thematically categorized into the following six topics.

\section{Reasons that the participants put forward for the rejection of FC}

The majority of participants in this study, with the exception of one man and one woman (36/38), expressed their rejection of all types of FC. However, different arguments were put forward for the discontinuation of the practice. Chiefly among them were that the practice causes health problems; is not a religious requirement; is a very painful experience with the potential to erode females' sexual feelings; and the social environment in Norway, which is supportive of its discontinuation.

With the exception of one person, the participants unanimously agreed that FC causes a number of health problems and is not a religious requirement. The majority of participants in this study agreed that the practice is a traditional culture as opposed to religious practice, yet some of them believed that the practice was introduced into their community in the name of Islam by Egyptians. Still, they rejected the practice, as they were fully convinced that the practice is un-Islamic.

It is wrong to circumcise girls because FC is prejudicial to their health. Women experience complications in child birth ... Above all, there is nothing that says that girls should be circumcised. It is just a myth that was passed to us by Egyptians, and has nothing to do with Islam. (19-year-old female)

I think FC is a wrong kind of tradition, it is not good for one's health and it has nothing to do with Islam. Look, our girls suffer health problems [due to FC], the retention of menstruation, etc. This must be stopped. (22-year-old male)

It should be stopped because it is not a religious requirement. It is a cultural thing and we live far away from that culture now ... I think FC will soon be history among Somalis in Norway. (43-year-old female)

This practice is not a religious requirement, and therefore we have to stop it. We have experienced its pain, so how could we subject the same pain to our daughter? (44-year-old female)

I am against it because my religion doesn't prescribe female circumcision. On top of that, it creates several health problems, and I have gone through all those complications. That is why I am against it. (43-year-old female)
Conversely, while most female participants justified their opposition to FC by stating that it is un-Islamic and painful, the majority of the male participants rejected the practice because of a belief that FC erodes females' sexual feelings. Many male respondents noted that circumcised women do not have any sexual feeling.

God has created women in a good condition, and it doesn't say that certain tissues should be removed from girls. The external genital tissues are created by God; if these tissues are cut, girls will no longer have any sexual feeling. (19-year-old male)

It is unacceptable to cut the human body and modify the way God has created women. What we are cutting is their reproductive organ. Most of the sexual feelings come from the clitoris. If it is cut, then it seems that the person is killed while still being alive. (43-year-old male)

I consider FC to be an unacceptable practice. The circumcised girls lack sexual pleasure, and experience complications in child delivery and have other health problems ...

(19-year-old female)

The respondents' abandonment of FC was also attributed to a supportive environment that exists in Norway, as opposed to the social pressure that perpetuates the practice in Somalia. Some participants believe that many Somalis in Somalia dislike FC, but they continue to perform it because of social pressures.

Somalis in Norway and those in Somalia may both dislike FC. But the environment they live in makes them different. If someone in Somalia doesn't circumcise their daughter, it may become an embarrassment to the entire family. Conversely, being uncircumcised is prestigious in Norway. So there is no pressure at all to do it there. (48-year-old male)

When I was at school, my schoolmates would have teased me if I was not circumcised like them. The fear of stigma overtook the damage that FC inflicts. When we came to Norway, we came to a place where FC is not practiced. (43-year-old female)

The majority of Somalis don't support FC, but the surrounding environment is pushing them to circumcise their daughters. If they don't, their daughter will be stigmatized by girls who are circumcised. In Norway, the majority of Somali girls are not circumcised, and thus circumcision is not a plus. (48-year-old male)

Some participants told painful stories of FC that had either happened to themselves or to their relatives, with the aim 
of justifying their abandonment of the practice. While most participants talked of their female relatives' painful experiences with FC, a 56-year-old male participant told about his own bad experience with the practice. These are their remarks:

To me, I had a bad experience with FC. My first marriage broke down because of FC. The problem of FC became obvious to me when I got into my first marriage. I married a lady, and when I was with her the first night, she rejected me. She refused to let me touch her body. I was surprised because I knew that she loved me, and that her family was happy that I had married their daughter. I couldn't understand what was wrong. Later, I understood that because she was sutured, there would be a tearing or cutting of sealed tissues during her first sexual encounter, and she knew that sex would cause her pain rather than pleasure. Men cannot imagine the pain and suffering that FC victims go through, but the women know it. Previously, I believed that FC was a way to protect women from rape, and I supported it. But when I experienced the problem, I rejected it. FC should be eradicated, and its practitioners should be prosecuted. (56-year-old male)

For example, my aunt had three girls, and one of them died while undergoing the circumcision procedure. My aunt was asked to stop the second daughter from undergoing the procedure because her first daughter had died. She said that she would not stop her from becoming circumcised because "her female schoolmates will stigmatize her." (43-year-old female)

On my first marriage, I was defibulated. The pain that I had gone through was no laughing matter. I don't want my children to have a similar experience. It was a difficult experience. (44-year-old female)

There is a lady who is my cousin. She was married in Somalia by an old man. She was a virgin and the old man wanted to devirginize her on the first night by using force. But he couldn't tear her sutured body by force. He took a knife and inserted the knife deep into her vagina, tearing her body. She bled a lot, and eventually fainted. There were people who reported her case to the United Nations Office for Refugees, and they eventually granted her resettlement to Switzerland where she now lives. It is quite clear that FC does not have any benefits. (43-year-old female)

\section{Presence of a minority group which supports circumcision}

While the majority of the study participants acknowledged that their community abandoned FC, they also repeatedly noted that there could be a minority group within the community who are sympathetic to the girls' circumcision but who cannot perform it because they are afraid of being prosecuted.

I think that the majority of the people I know are against FC. There may be a few who, if they were at home [Somalia], would have circumcised their daughters. But they don't circumcise them here because they are scared of the law. (56-year-old male)

I am against FC. The majority of Somalis in Norway don't want the practice, but there is a minority group who would have done it, but they cannot because Norwegian law forbids it. (54-year-old male)

There is a saying, "If you are in a place where people are all blind, you are also better off to be blind." Norway is a country where people don't know FC. Somalis in Norway have stopped FC as well. There are also a few people who are scared of the law. (56-year-old male)

In accordance with the above statement, one female participant reported that she would have circumcised her daughter using the mildest form, but she could not do so because Norwegian law forbids it. She believes that a minor version of circumcision would have provided moral support to her daughter in that she would not feel different from others.

I would have circumcised my daughter, but I am scared of the law. If it was not for the law, I would have circumcised her with the sunna form. I am totally against the Pharaonic form where all the external tissues are removed and then the opening is sutured. With the sunna form, a drop of blood is obtained from the clitoris and there are no problems at all. If my daughter is circumcised using the sunna form, she would feel no different from the other girls. She knows that I am circumcised, she knows that my mother was circumcised and she knows that circumcision is part of our culture. She knows that people in the West are not circumcised. If she is circumcised with the sunna form, she would feel happy. (39-year-old female)

One male participant who had lived in Norway for two years supported the practice, and attributed to it the dignity and honor of the girls and women. He mentioned that he does not have any evidence that the practice is a religious requirement, but he admitted that he feels that circumcision is advantageous for girls and women.

In our culture, girls are circumcised, but I haven't seen any religious book that prescribes it. However, to me, FC is part of a good culture that girls benefit from. I am from Mogadishu, where girls are very polite. I have been to 
many countries in Europe, Asia, and Africa where girls are not circumcised, and they are very different. FC is a good practice. (24-year-old male)

\section{Perspectives of parents who did not circumcise their daughters}

Almost half of the study participants had daughters, and none of them had his/her daughters circumcised. Not only did they not circumcise their daughters, but most of them said that they were proud of their decisions. This was an idea shared by both men and women. At least one male participant reported that his uncircumcised girls are now married, and had no problems in their marriages.

There are girls who are my stepdaughters that have been under my custody throughout their entire life. They were not circumcised, and they are married now. It is something that I am proud of. They are married today, and they haven't experienced any problems in their marriage. (54-year-old male)

Because I learned that our religion doesn't accept it, I stopped circumcising my daughters. I have five daughters and I didn't circumcise any of them. (48-year-old female)

My daughters were born in Norway, and they got a shock the first time they were told about circumcision. I don't like them hearing about circumcision. (37-yearold mother of four daughters, who has had none of them circumcised)

I am happy that I left my daughter the way she was born. I am happy that she has not gone through the pain of circumcision. My daughter was born here and she doesn't know my Somali culture. She always asks me about it. I think if I circumcise my daughter, she will curse me and she will never forgive me. I cannot forget the pain of circumcision, even at this old age. (43-yearold female)

I have two daughters and I didn't circumcise them, and their children (his grandchildren) will not be circumcised. I believe it is a harmful culture. Every harmful culture has a time for it to be eradicated; I think it is time for FC to be eradicated. (54-year-old father of four daughters)

\section{Respondents' perceptions toward uncircumcised girls}

Almost all of the participants from both genders agreed that uncircumcised girls in Oslo are not only healthier than the corresponding group of circumcised girls, but also have a higher chance of being married to a Somali man. Thus, the noticeable indication during the FGDs was the fact that young girls who were uncut and those with milder forms of FC (sunna) repeatedly and superciliously proclaimed their circumcision status, thereby confirming their better health status, while circumcised participants acknowledged that the uncut participants were luckier and healthier than they were. Another revelation was that, with the exception of one, all the male members expressed their admiration for uncut women. The reasons put forth were that uncircumcised women enjoy sex more and are healthier. Similarly, the vast majority of female participants acknowledged that cut girls had little attraction to the current male generation. In support of this, three female participants reported that they are often asked about their circumcision status by men, and when they state that they are circumcised, the men never come back to them again.

I agree that uncircumcised girls are healthier. Regarding sexual feeling, they enjoy sex much better than circumcised women. (37-year-old female)

When young men talk about marriage, they mostly always express their desire to marry uncircumcised women. There is a perception that uncircumcised women are more sexually active than circumcised women ... We believe that our sons are luckier than us. The reason is that they will get married to uncircumcised girls. The effect of circumcision not only affects the lives of the women, but also affects us. (48-year-old male)

Uncircumcised girls have a special quality for me. I will marry an uncircumcised one. During circumcision, the sensitive genital tissues are cut. I would prefer [to marry] one who has all her tissue (uncircumcised). (19-year-old male)

A friend of mine who uses "Facebook" told me that when he meets a girl, he always asks "if she is circumcised," and if she says yes, he terminates the discussion. The boys in Norway want uncircumcised girls, and the parents know that their daughters will be better off without circumcision. (48-year-old male)

I talk to men often, and they always ask me about uncircumcised women. There were times I told the men that I know uncircumcised women, and they used to call me every day asking me for their telephone numbers, etc. (37-year-old female)

Men always ask if I am circumcised or not, that is their first question. I ask them why they ask that question, but it seems that they don't want circumcised women. (26-year-old female) 


\section{Uncertainties surrounding the transition from cut to uncut}

Despite the participants' overwhelming rejection of the practice, the transition from cut to uncut behavior has generated concerns over the consequences of people's new behavior. Two mothers with a total of six uncut daughters told of their worries over this new behavior.

My daughters are too young, but I often think about them. How will their clitoris look when they grow up? They will wear trousers. Will it project from the trousers? I was circumcised, and I didn't know how things would look like; I worry about it. (48-year-old female)

First of all, I share my friend's concern over the probable growth of the clitoris and how it is going to look. We have never seen it. Secondly, we were circumcised and our mothers knew that we were virgins. But we cannot know what our uncircumcised daughters are doing. Whenever my daughter feels sick, I tell myself that "maybe she is pregnant"; it's worrisome. (44-year-old female)

\section{Pressure from grandmothers who stay in Somalia}

Although FC received strong opposition among the study participants, it is clear that the participants were caught between their own belief toward FC and pressure from grandmothers in Somalia. Some of the participants believe that the hurdle over the elimination of $\mathrm{FC}$ among immigrants may be because of pressure from back home. This pressure was repeatedly demonstrated by the participants:

The last time I travelled to Somalia, I met my grandmother, who is very old. She asked me if my daughter was circumcised. I told my grandmother that my daughter was circumcised. I didn't tell her the truth because I didn't want to say that she was not circumcised. She felt happy that my daughter was circumcised. If I didn't lie, she might have stolen my daughter when I went out and circumcised her. She is an old person who is strict about her old culture. The young generations have learned about the problem that FC causes, and that is why we don't want to circumcise our daughters. (43-year-old female)

My mother always asks me about my daughters. I told her that I don't want them circumcised, and she says "Who is going to marry them if they are not circumcised? It is a shame that the daughters are not circumcised." I try to convince her that my daughters have contemporaries who live here and who don't believe in FC, and that they will marry their contemporaries in Norway. (37-year-old female)

\section{Discussion}

To the best of our knowledge, the current study is the first to examine the attitude of Somali immigrants regarding the continuation or discontinuation of girls' circumcision in Norway. The result shows that FC, which was formerly considered a form of cleanliness and an essential religious requirement, is now considered by Somali immigrants in Oslo as harmful, barbaric, and un-Islamic. Although strong support for the continuation of FC among women in Somalia was reported, ${ }^{2}$ the present study shows that a "life in exile" has positively affected Somalis' attitudes toward FC. This result confirms prior assumptions that in areas in which $\mathrm{FC}$ is not associated with social status by the majority, social factors that influence its continuation may be reversed. ${ }^{14,19}$

Surprisingly, the same factors that were initially used to justify the continuation of the practice in Somalia are now used by the participants as good reasons for its abandonment. With the exception of one man, all of the participants agreed that there are no Godly laws that support the practice and that the practice is traditional and in conflict with Islamic principles. The continuation of FC among Somalis has been largely associated with the community's view that FC is a religious obligation. ${ }^{2}$ Thus, an improved knowledge regarding the religious aspect of FC observed among Somalis in Oslo reveals that major progress toward the abandonment of $\mathrm{FC}$ is being made in Norway. The existence of an enabling environment that is unfavorable for the continuation of $\mathrm{FC}$, as well as an improved knowledge of the health effects of the practice, is central to the observed rejection of FC among Somali immigrants in Oslo.

One of the unexpected findings in this study was the fact that being uncut was seen by both female and male participants as giving a person a higher status. This is divergent from the initial perception in which being uncut was seen by Somalis as an embarrassment not only to the girls, but also to their entire families. Moreover, the majority of male participants in this study noted that they wanted uncut girls over circumcised ones for marriage. This is an indication of the fact that the longer being uncut is seen as prestigious among Somali immigrants, the higher the likelihood that the practice will disappear faster than expected in this community. Most parents carry out circumcision to enhance their daughters' chances for marriage; however, in this study, the vast majority of male participants indicated that they want to marry uncut girls. Since most Somali men in Oslo prefer to marry uncircumcised over circumcised women, it is unlikely that parents in Oslo will circumcise their daughters knowing that FC could only make their daughters worse off. 
Because of the unrepresentative nature of our sample, we cannot conclude that Somali immigrants in Oslo have changed their behavior toward FC. But the most important finding in this study is the presence of parents in Oslo who publicly declared that they did not circumcise their daughters and that uncircumcised girls were proud of being uncut, which is called a "positive deviant group." The conventional theory postulates that the practice can be terminated through the existence of a group of parents who reject circumcising their daughters. ${ }^{43}$ This is supported by diffusion theory, which postulates that new behaviors are not adopted by all people at once, but are often started by a group of innovators; diffusion then occurs until a critical mass is eventually achieved..$^{44}$ The time is right to declare that most Somali immigrants in Oslo have changed their behavior, and that most of the Somali girls who were born or brought up in Norway are left uncircumcised for good reasons. This finding is supported by earlier quantitative findings which have reported that almost all Somali female participants who were either born or came to Norway at the age of $\leq 5$ years (under publication) were not circumcised ( $14 \%$ of the total women). This finding is also supported by prior qualitative studies that postulated that Somalis in Norway are likely to abandon FC. . $^{14,45}$

Unfortunately, despite the presence of a number of qualitative studies in different Western countries that have postulated the likelihood of an abandonment of FC among Somali immigrants, ${ }^{14,17,19,34,45}$ as well as the absence of recent empirical evidence which supports Somali girls still undergoing circumcision, most recent campaigns on FC use stereotypical old messages that have been used for generations in Africa, without any consideration for the dynamic nature of human behavior and the effects of acculturation and social environment on immigrants' behavior. Therefore, national and international programs should harness their campaign strategies to research-generated knowledge so that the campaign messages are consistent with the levels of behavior and attitude change of local communities toward girls' circumcision.

Some of the study participants who abandoned the practice have expressed concerns over their new uncut behavior. Obviously, the transition period between all cut and all uncut states could be the definitive moment from which people are either overwhelmed by concerns over their new behavior and ultimately revert to an old undesirable behavior, or to sustainably adopt the desired new behavior and become skillful in deflecting all types of pressure. Because of this, parents who have changed their behavior and left their daughters uncut will require an effective strategy that enables them to overcome dilemmas, counteract opposition and resist pressure, and which helps to promote and diffuse their new behavior to others in Norway and to kinship networks in Somalia.

While parents in Norway do not want their daughters circumcised, they feel pressure from grandparents in Somalia who push them to circumcise their daughters. In Somali culture, decision making is hierarchical and is shared by extended family members, including the father, mother, grandmother, grandfather, parents-in-law, etc. The decision made by grandparents is often the most respected. Even so, the decision-making hierarchy among Somalis has, to some extent, been neutralized by the migration where, as in Norway, mothers are empowered to have the last word on decisions that concern them and their children. Yet, in this interconnected and powerful hierarchical society, the grandmother's word still carries significant importance. Thus, the pressure posed by grandparents regarding the circumcision of girls can be a real threat to elimination of the practice among Somalis in exile. As a result, awareness campaigns and efforts against FC should be extended to FC-practicing countries which serve as a source of pressure on immigrants in the West.

This study has limitations. The results of the study reflect the perceptions of a limited number of people who participated in the study, and not necessarily those of the entire Somali immigrant population in Oslo. The failure to generalize the findings of this study to the Somali immigrants in Norway is a general limitation of the qualitative methods used. Most of the views and opinions were repeatedly expressed among different individuals in both the FGDs and personal interviews, thereby increasing our confidence in the validity of the findings.

\section{Conclusion}

This study demonstrates that changes in behavior toward FC among Somalis in Oslo are imminent and that parents are making choices to save their daughters from this harmful tradition. Consequently, the time is right to start campaigns that target behavioral changes toward the practice, using those who have already abandoned the practice as community role models. This is one step forward from the attitude-change campaigns in which increasing knowledge in the communities was the goal. The existing literature argues that foot binding in China and FC in Africa are similar traditional practices; therefore, factors that led to the eradication of foot binding in China can also be used to eradicate FC in Africa. ${ }^{46}$ Among strategies used by reformers to end foot binding in 
China was the formation of a "natural foot society," whose members rejected the binding of their daughters' feet. The same applies to the current situation in Oslo, where the organizing of parents who reject the practice, together with their daughters to form an "uncut society," could be a motivation to others and thus a symbol of the beginning of a mass abandonment of FC in Norway.

\section{Acknowledgments}

We wish to thank Save the Children Norway for their leadership role in the project and for their constructive contribution during the application write-up and throughout the implementation of the study. We would also like to thank Kristin Narum, Bente Bø, Ivan Harsløf, Sara Kahsay, and Sissel Seim for their valuable input to the project. The study was funded by the Foundation of Health and Rehabilitation, Norway.

\section{Disclosure}

The authors declare that they have no competing interests in this work.

\section{References}

1 World Health Organization (WHO). Female Genital Mutilation: An Overview. Geneva: WHO; 1998. Available from: https://apps.who.int/ dsa/cat98/fgmbook.htm. Accessed December 2, 2011.

2. The World Bank, United Nations Population Fund. Female Genital Mutilation/Cutting in Somalia. Washington, DC: World Bank, United Nations Population Fund; 2004. Available from: http:// siteresources.worldbank.org/INTSOMALIA/Data\%20and\%20Reference/20316684/FGM_Final_Report.pdf. Accessed December 2, 2011.

3. Johansen RE, Barre A, Sundby J, Vangen S. Just a little incision. Tidsskr Nor Laegeforen. 2004;124(19):2506-2508. Norwegian.

4. Creel E. Abandoning Female Genital Cutting: Prevalence, Attitudes, and Efforts to End the Practice. Washington, DC: Population Reference Bureau; 2001. Available from: http://www.prb.org/pdf/AbandoningFGC_Eng.pdf. Accessed December 2, 2011.

5. WHO. Eliminating female genital mutilation: An interagency statement UNAIDS, UNDP, UNECA, UNESCO, UNFPA, UNHCHR, UNHCR, UNICEF, UNIFEM, WHO. Geneva: WHO; 2008. Available from: http://whqlibdoc.who.int/publications/2008/9789241596442_eng.pdf. Accessed December 2, 2011.

6. Alsibiani SA, Rouzi AA. Sexual function in women with female genital mutilation. Fertil Steril. 2010;93(3):722-724.

7. Ndiaye P, Diongue M, Faye A, Ouedraogo D, Tal DA. Female genital mutilation and complications in childbirth in the province of Gourma (Burkina Faso). Sante Publique. 2010;22(5):563-570. French.

8. Banks E, Meirik O, Farley T, et al. WHO study group on female genital mutilation and obstetric outcome. Female genital mutilation and obstetric outcome: WHO collaborative prospective study in six African countries. Lancet. 2006;367(9525):1835-1841.

9. Ibrahim A, Rasch V, Pukkala E, Aro AR. Cervical cancer risk factors and feasibility of visual inspection with acetic acid screening in Sudan. Int $J$ Womens Health. 2011;3:117-122.

10. WHO. World Health assembly calls for termination of harmful traditional practices. Geneva: WHO; 1993.

11. Toubia NF, Sharief EH. Female genital mutilation: Have we made progress? Int J Gynecol Obstet. 2003;82(3):251-261.
12. Darkenoo E. 6000 girls at risk every day. Female genital mutilation, although illegal, is still widely practiced. Womens Health Newsl. 1993;(20):10-11.

13. UNICEF Innocenti Research Centre. Innocenti Digest: Changing a Harmful Social Convention: Female Genital Mutilation/Cutting. New York, NY: UNICEF; 2005. Available from: http://www.unicef-irc. org/publications/pdf/fgm_eng.pdf. Accessed December 2, 2011.

14. Talle A. Kulturens makt. [The Power of Culture] Kristiansand: Norwegian Academic Press; 2010. Norwegian.

15. Essen B, Jonsdotter S. Female genital mutilation in the West: traditional circumcision versus genital cosmetic surgery. Acta Obstet Gynecol Scand. 2004;83(7):611-613.

16. Johansen B. Pain as a counterpoint to culture: toward an analysis of pain associated with infibulation among Somali immigrants in Norway. Med Anthropol Q. 2002;16(3):312-340.

17. Johnsdotter S. Created by God: How Somalis in Swedish Exile Reassess the Practice of Female Circumcision. Dissertation. Lund: Lund University; 2002. Available from: http://mah.academia.edu/ SaraJohnsdotter/Books/78503/Created_by_God_How_Somalis_in_ Swedish_Exile_Reassess_the_Practice_of_Female_Circumcision_ Doct._diss._Lund_University_2002_. Accessed December 2, 2011.

18. Johnson CE, Ali SA, Shipp MP. Building community-based participatory research partnerships with a Somali refugee community. Am J Prev Med. 2009;37(6 Suppl 1):S230-S236.

19. Morison L, Dirir A, Elmi S, Warsame J, Dirir S. How experiences and attitudes relating to female circumcision vary according to age on arrival in Britain: A study among young Somalis in London. Ethn Health. 2004:9(1):75-100.

20. Dirie MA, Lindmark G. Female circumcision in Somalia and women's motives. Acta Obstet Gynecol Scand. 1991;70(7-8):581-585.

21. Gallo PG. Female circumcision in Somalia: some psycho-social aspects. Genus. 1985;41(1-2):133-147.

22. Ntiri DW. Circumcision and health among rural women of Southern Somalia as part of a Family Life Survey. Health Care Women Int. 1993;14(3):215-226.

23. Magoha GAO, Magoha OB. Current global status of female genital mutilation: a review. East Afr Med J. 2000;77(5):286-272.

24. Morris R. The culture of female circumcision. ANS Adv Nurs Sci. 1996;19(2):43-53.

25. Imam Abdinur M. Islam and female circumcision. In: Nina F, editor. Circumcision: Stop. Oslo: Cappelen Damm Ass; 2010:63-75.

26. Edien B. Female circumcision among immigrant Muslim communities: public debate in the Netherlands. Journal of Muslim Minority Affairs. 2004;24(2):393-399.

27. Lane S, Robert A. Judging the other: Responding to traditional female genital surgeries. Hastings Center Report. 1996;26(3):31-40.

28. Helman CG. Culture Health and Illness. 5th ed. London: Hodder Arnold; 2007.

29. Vissandjée B, Kantiéb M, Levine A, N'Dejuru R. The cultural context of gender, identity: female genital, excision and infibulation. Health Care Women Int. 2003;24(2):115-124.

30. Vangen S, Stoltenberg C, Johansen RE, Sundby J, Stray-Pedersen B. Perinatal complications among ethnic Somalis in Norway. Acta Obstet Gynecol Scand. 2002;81(4):317-322.

31. Norwegian Ministries. Action Plan for Combating Female Genital Mutilation: Action Plan 2008-2011. Oslo: Ministry of Children and Equality; 2008. Available from: https://www.politi.no/vedlegg/skjema/ Vedlegg_668.pdf. Accessed December 2, 2011.

32. Tonje B. How big is the scope of female circumcision in Norway? In: Nina F, editor. Circumcision: Stop. Oslo: Cappelen Damm AS; 2010:77-93.

33. Black J, Debelle G. Female genital mutilation in Britain. BMJ. 2011; 310(6994):1590-1592.

34. Johnsdotter S. Somali women in western exile: Reassessing female circumcision in the light of Islamic teaching. Journal of Muslim Minority Affairs. 2010;23:361-373.

35. Upvall MJ, Mohammed K, Dodge PD. Perspectives of Somali Bantu refugee women living with circumcision in the United States: A focus group approach. Int J Nurs Stud. 2009;46(3):360-368. 
36. Kitzinger J. Qualitative research. Introducing focus groups. BMJ. 1995;311(7000):299-302.

37. Morse M, Field P. Qualitative Research Methods for Health Professionals. Thousand Oaks, CA: Sage; 1995.

38. Braun V, Clarke V. Using thematic analysis in psychology. Qualitative Research in Psychology. 2006;3(2):77-101.

39. Boyatzis R. Transforming Qualitative Information: Thematic Analysis and Code Development. Thousand Oaks, CA: Sage; 1998.

40. Leininger M. Ethnography and ethnonursing: models and modes of qualitative data analysis. In: Leininger M, editor, Qualitative Research Methods in Nursing. New York, NY: Grune and Stratton; 1985;33.

41. Taylor S, Bogdan R. Introduction to Qualitative Research Methods: The Search for Meanings. New York, NY: Wiley and Sons; 1984.

42. Berkowitz S. Analyzing Qualitative Data. In: Frechtling L, Sharp, L, Westat LS, editors. User-Friendly Handbook for Mixed Method Evaluations. Washington, DC: National Science Foundation; 1997.
43. Mackie G. Female genital cutting: the beginning of the end. In: Shell-Duncan B, Hernlund Y, editors. Female "Circumcision" in Africa: Culture, Controversy, and Change. Boulder, CO: Lynne Riener Publishers; 2000.

44. Rogers E. Diffusion of Innovation. 5th ed. New York, NY: Free Press; 1962.

45. Johansen B. Experience and Perceptions of Pain, Sexuality and Childbirth: A Study of Female Genital Cutting among Somalis in Norwegian Exile, and their Health Care Providers. PhD thesis. Oslo: Oslo University; 2006.

46. UNICEF. Female Genital Mutilation/Cutting: A Statistical Exploration. New York, NY: UNICEF; 2005. Available from: http://www.unicef. org/publications/files/FGM-C_final_10_October.pdf. Accessed December 2, 2011.
International Journal of Women's Health

\section{Publish your work in this journal}

The International Journal of Women's Health is an international, peerreviewed open-access journal publishing original research, reports, reviews and commentaries on all aspects of women's healthcare including gynecology, obstetrics, and breast cancer. Subject areas include: Chronic conditions (migraine headaches, arthritis, osteoporosis);

\section{Dovepress}

Endocrine and autoimmune syndromes; Sexual and reproductive health; Psychological and psychosocial conditions. The manuscript management system is completely online and includes a very quick and fair peer-review system. Visit http://www.dovepress.com/ testimonials.php to read real quotes from published authors.

Submit your manuscript here: http://www.dovepress.com/international-journal-of-womens-health-journal 